The University of Akron

\title{
IdeaExchange@UAkron
}

Proceedings from the Document Academy

University of Akron Press Managed

December 2016

\section{The Curious Case of Floating Fixity (and its Relationship to Authenticity)}

Kiersten F. Latham

Kent State University, kflatham@kent.edu

Please take a moment to share how this work helps you through this survey. Your feedback will be important as we plan further development of our repository.

Follow this and additional works at: https://ideaexchange.uakron.edu/docam

Part of the Library and Information Science Commons, and the Museum Studies Commons

\section{Recommended Citation}

Latham, Kiersten F. (2016) "The Curious Case of Floating Fixity (and its Relationship to Authenticity),"

Proceedings from the Document Academy: Vol. 3 : Iss. 2 , Article 2.

DOI: https://doi.org/10.35492/docam/3/2/2

Available at: https://ideaexchange.uakron.edu/docam/vol3/iss2/2

This Conference Proceeding is brought to you for free and open access by University of Akron Press Managed at IdeaExchange@UAkron, the institutional repository of The University of Akron in Akron, Ohio, USA. It has been accepted for inclusion in Proceedings from the Document Academy by an authorized administrator of

IdeaExchange@UAkron.For more information, please contact mjon@uakron.edu, uapress@uakron.edu. 


\section{Introduction}

In 2016, I presented two conference papers - within a month of each other-on authenticity in the museum context. In the midst of preparing for these talks, I had a revelation about authenticity during a family holiday. It is that revelation, which I call The Story, that I share and discuss with you here because the experience raised issues we often discuss in document/ation studies. In this article, I will use this story of my revelation as a point of departure to utilize the framework outlined by Tim Gorichanaz and I (Gorichanaz \& Latham, 2016) in our paper on holistic document analysis. The story is personal but also embedded into my professional life and therefore serves as a good situation to dissect using the framework. My conclusions are tentative as this is more of an exercise than anything else. I hope it inspires others to "play around with" document situations in their own lives as well.

\section{The Context for The Story}

Since discovering the world of the Document Academy (DOCAM) many years ago, I have been grappling with the notion of "fixity." I think it's safe to say that most DOCAM participants agree that fixity is not a reality. Over the years, I have painfully come to the same conclusion. For me, there is a kind of comfort in fixity so it hurts a little to admit that it is an illusion. In fact, this concession has led me to inquire even more about fixity, fluidity, and the meaning of documents. In early 2016, I attended two conferences which had authenticity in museums as a theme; one was international (Leibniz Research Alliance's Historical Authenticity in Mainz, Germany; Latham, 2016a) and the other a regional U.S. symposium (Historical Administration Program Association (HAPA) symposium at Eastern Illinois University (Latham, 2016b). At both, I talked about the meaning of authenticity in the museum context, in conjunction with my ongoing research on visitor perceptions of 'the real thing' (Latham, 2015). While working on these two presentations-a very intense period of time investigating authenticity in early 2016-I came to an understanding that has helped me make some sense of both fixity and authenticity in the context of memory institutions and documents. 


\section{The Story: My Irish Peat Bog Experience}

My realization came to me in a very clear moment, standing on the bogs of Western Ireland. During my recent trips to Ireland (2014 and 2016), I witnessed the whole-scale scraping of the peat bog surface and was devastated to learn that nearly $90 \%$ of the Irish peat bogs have been disturbed in some way. Peat of course, has many modern uses-fuel, fertilizer, etc. I had been tormented by this loss and felt powerless in wishing to save the bogs as the problem seemed so massive (and perhaps too late). As a child, I was fascinated with the 'bog people,' the miraculously preserved ancient individuals that were found in peat bogs. It was probably one of the contributing factors to my becoming a physical anthropologist (my first career). Because of this, I felt a connection to Ireland, the peat bogs, and the bog people. Driving by these bogs, watching the giant machines scrape up thousands of years of decay, made my heart hurt.

Figure \#1. The peat bog walk in Ireland with interpretive signage. Author's photo.

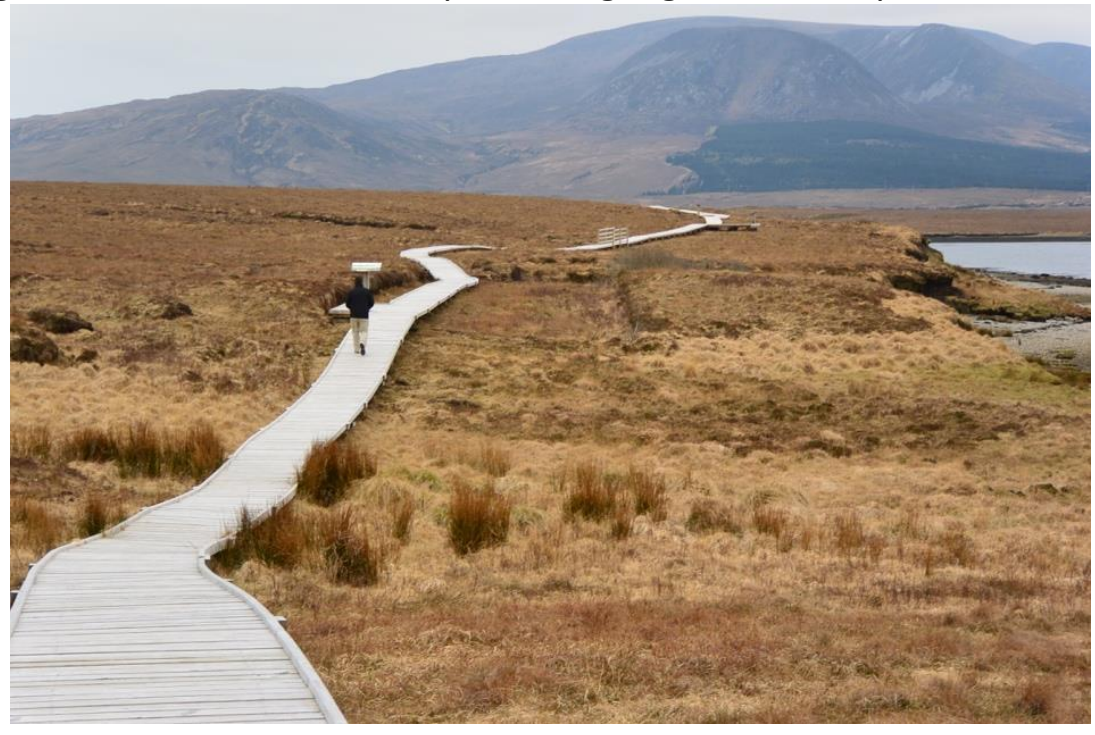

And then came that moment in March 2016, sandwiched between the two authenticity conference talks, when I was standing on the bog in Western Ireland. There was a lovely wooden walk over the bog, with interpretive signage (Figure \#1). It was in the middle of Nowhere and was just beautiful. We were alone with the bog, up close and personal. Then I read one of the interpretive signs, which were obviously new installations. It explained that the bogs of Ireland were there because of Neolithic peoples' clearing of the land. Prior to this, Ireland was covered in pine, oak, and elm forests, but Neolithic farmers altered the very being of this island by clearing these forests for farming. It was people who created (unintentionally) the bog! The bog was not "natural to" original Ireland. The moment was distinct and almost visceral; the heartache abruptly ceased. Like a light switch, I was no longer tormented by the modern scraping of the peat bogs.

I realized then that my perception of an authentic environment (thing, document, whatever you want to call it) had to do with a fixed point and where that point was placed, logically or arbitrarily so. In other words, where I placed that fixed point is where I based my notion of authenticity. In this case, something is authentic when it is original and how one perceives original depends on where that point is placed. In other words, the point of fixity is floating, it moves depending on a set of circumstances surrounding the person-document transaction. It could be logically placed (eg. a clearly identified change in context) or arbitrarily placed (eg. critics and experts interpret the start of a movement). The notion of floating fixity helped me make sense of issues that had come up in both my conference talks, providing me with very important insight into perceptions of authenticity in museums. But what exactly is going on with floating fixity, I wondered? 


\section{Authenticity and Fixity: Quick Definitions}

A lot has been said about both authenticity and fixity, from many different perspectives and disciplines. For the sake of moving to the issue at hand, I am going to contend here that something that is authentic is what it says it is (see Skare, 2015 Proceedings of the Document Academy for a very good quick review of a complex literature on the topic; see also cf. Grayson \& Martinec 2004, Hede \& Thyne, 2010 for further related discussion). I could provide you here with all kinds of grey areas from my own research on The Real Thing in museums (what people in my research say) but that I will reserve for another time. The literature on fixity is equally complex, although perhaps not as convoluted. While it is not as difficult to define as authenticity, it is tricky nevertheless, and often bound up in definitions of authenticity. Here I will define fixity as "the state or quality of not changing" (Merriam Webster, 2016).

\section{A Document Analysis of My Peat Bog Experience}

Instead of diving into a potentially deep morass of academic "he said/she said" around these complex concepts, I would like to instead use the recent document analysis tool published by Tim Gorichanaz and myself (Gorichanaz \& Latham, 2016) to pull apart my peat bog experience in an attempt to understand what occurred as well as to clarify the notion of floating fixity. Document phenomenology, as we call it, is a framework that attempts to take a more holistic look at documents, their contexts, and the people that transact with them. Keeping in mind that all documents need an agent to perceive it to become a document, we suggest four types of "information" contribute to documental meaning, two "from the object ${ }^{\mathrm{ii} \text { " }}$ and two "from the person," (see Figure 2). Using these concepts helped me to sort out what occurred between me and the peat bogs in early 2016. I will go through each of the four informations, define each one, then illustrate each using the Bog Experience Story. I should note that my analysis here is only using the first half of the framework, what we call "Act One." There are further steps that can be taken in Act Two of the Framework.

Figure 2. The Four Informations of a Document Transaction from Gorichanaz \& Latham, 2016. See a larger version of this graphic at the prezi for the DOCAM talk.

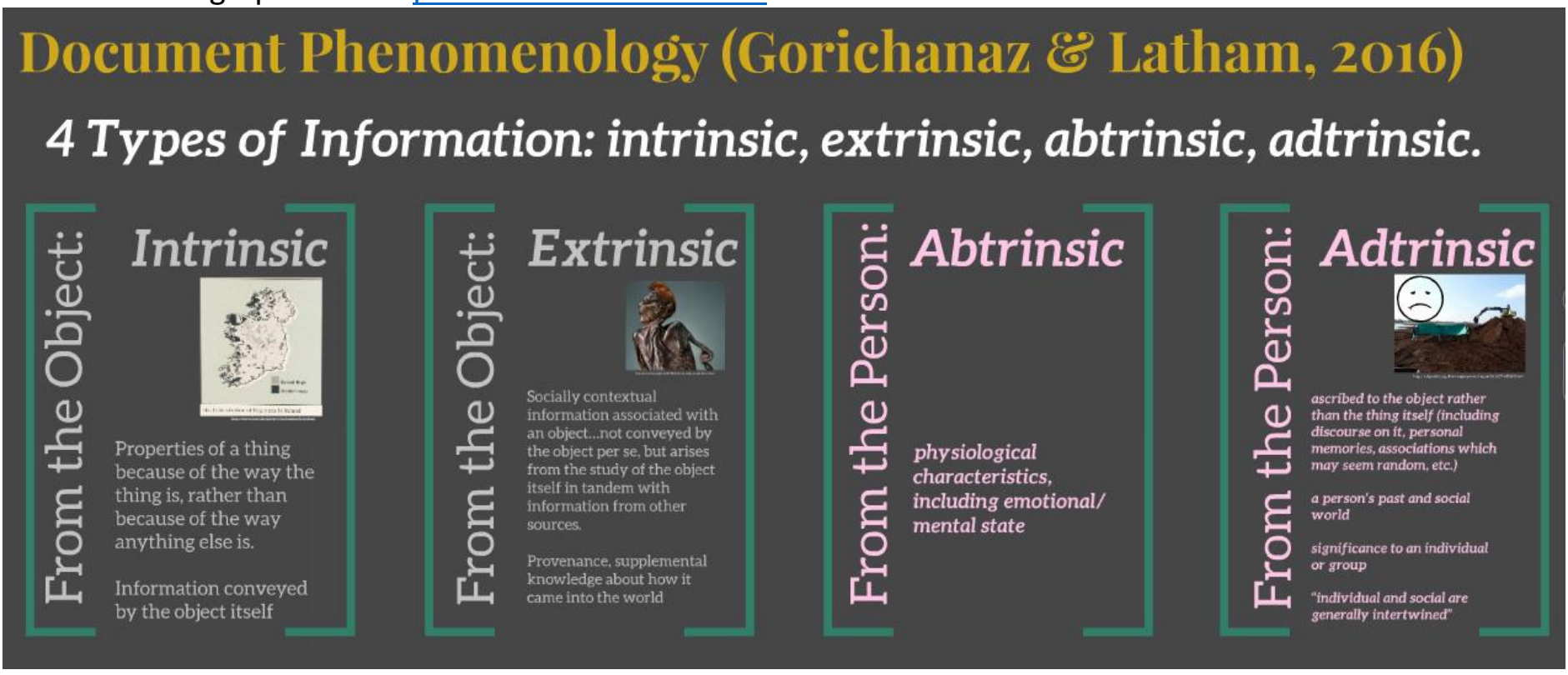

From the object, the two types of informations are intrinsic and extrinsic (all are from Gorichanaz \& Latham, 2016):

- Intrinsic information: information conveyed by the object itself; properties of a thing because of the way the thing is. 
- Eg: The peat bog is wet, spongy ground of decomposing vegetation; it has poorer drainage than a swamp; the soil is unfit for cultivation but can be cut and dried and used for fuel (dictionary.com, 2016).

$\circ$ Eg: Ireland has many peat bogs, $1 / 6$ of the island, which form over hundreds or thousands of years (Abbott, 2016).

- Eg: $90 \%$ of the peat bogs in Ireland are gone due to human use (Murray, n.d.).

- Extrinsic information: the socially contextual information associated with an object; not conveyed by the object per se, but arises from the study of the object itself in tandem with information from other sources; provenance, supplemental knowledge about how it came into the world.

- Eg: The peat bogs are a source of rich history in that many human sacrifices from the past occurred here and the composition of the bogs themselves caused detailed preservation of human remains (hair, skin, makeup, clothes etc) from which scientists have learned much about past life on the Island.

From the person, the two types of informations are abtrinsic and adtrinsic:

- Abtrinsic information: physiological characteristics, including emotional/mental state.

- Eg: I am sad to see all the machines digging up the peat bogs in Ireland on my recent trips there.

- Adtrinsic information: ascribed to the object rather than the thing itself (including discourse on it, personal memories, associations which may seem random, etc.); a person's past and social world; significance to an individual or group (the individual and social are intertwined).

O Eg: My childhood reading and dreaming about the bog people of Ireland, Denmark, UK.

- Eg: My association between "Irish" and "peat bogs" due to the bog people.

- Eg: My understanding that peat bogs were "natural"

- Eg: My memories of reading about the loss of the bogs and how devastating it has been for Ireland.

Figure 3. A graphic illustration of the document transaction between me and the peat bogs using Document Phenomenology, Act One. See a larger version of this graphic at the prezi for the DOCAM talk.
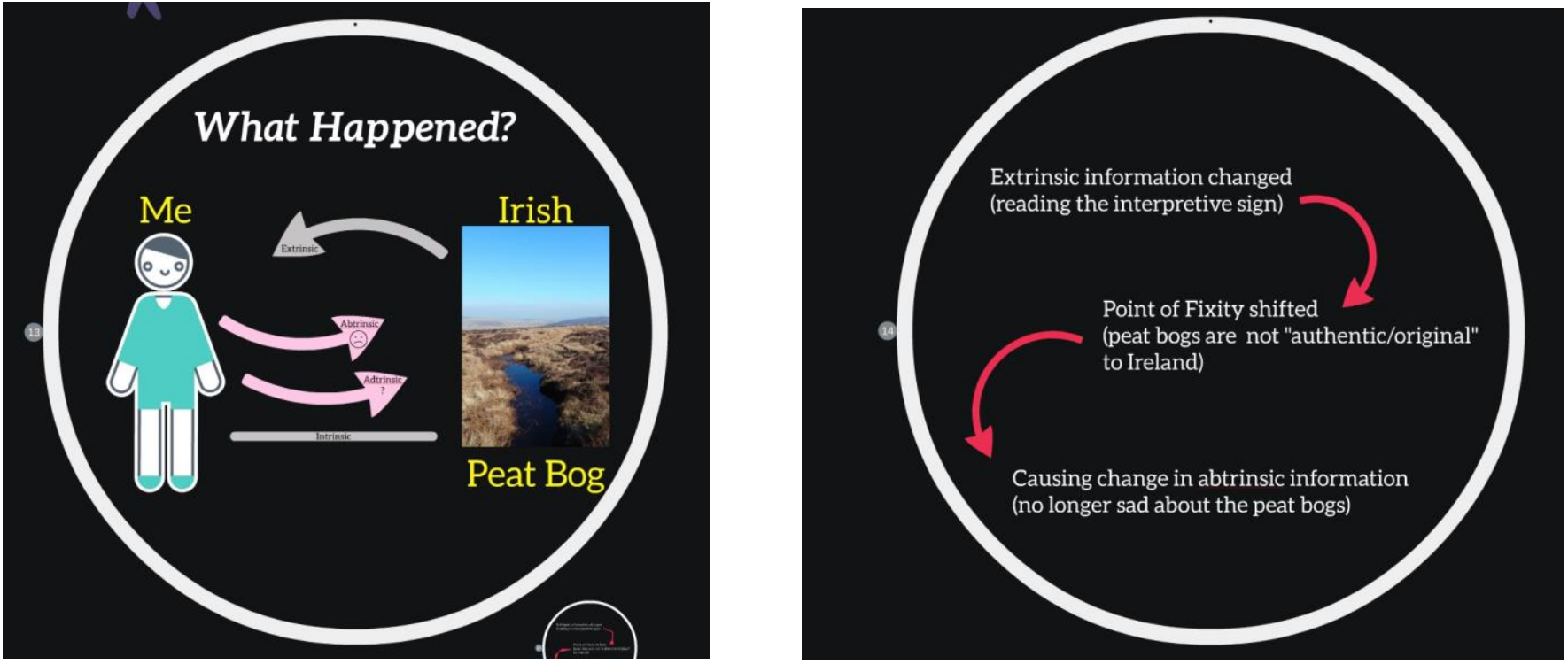

Using the Framework, Act One, helped me to see why something that had been so strongly felt about peat bogs suddenly shifted (see Figure 3). For most of my life, I believed that the peat bogs of Ireland were "original" to Ireland and that this was a part of the identity of Ireland, its history, and character. When I came into contact with the new interpretive signage on the bog in 2016, the extrinsic information - that the Irish peat bogs began when Neolithic peoples cleared the lands $5 k$ years ago and changed the environment, 
replacing a massive forest-around the bog changed causing a shift in both abstrinsic and adtrinsic information about peat bogs. For me, this extrinsic change or understanding about the peat bogs, shifted the point of fixity. If the point of "origin of Ireland" did not include bogs, but rather was a result of human manipulation, then my concern about an "authentic" Ireland was moot. This led to a change in abtrinsic information around the bogs, that I was suddenly no longer sad about the destruction of the bogs (individual and social intertwined). The visceral feeling I felt at that moment was an abtrinsic change. Another change has begun in the process of shifting adtrinsic information around these bogs as documents. Of note, is that the intrinsic information-the bogs themselves, including their massive modern destruction-did not change.

\section{A Curious Conclusion}

So why is this a curious case? And what do we make of this notion, floating fixity, a seeming oxymoron? The curious nature of floating fixity is that a document can be both fixed and fluid-at the same time. The same document, we saw here with my peat bog transaction, was fixed intrinsically (from the object), but fluid adtrinsically and abtrinsically. Brown and Duguid brilliantly stated this in 1996 in their now seminal piece, The Social Life of Documents, "we should consider a symbiosis between the two..." (p12) and they point out about art [i.e. documents]:

A century ago, the French poet Baudelaire claimed that art is half 'the transient, the fleeting, the contingent' and half 'the eternal and the immutable'... the idea of an interchange between the immutable and the transient, the fixed and the fleeting seems central to understanding documents and their many uses (p12).

Regarding the fixity and fluidity of documents, David Levy similarly said both are capable of both (Levy, 1994). The same can be said for authenticity, as it is so intricately wound up in issues of fixity. Floating fixity depends on agreed upon fixed points (socially, extrinsic) and perceived fixed points (adtrinsic). For example, in museums, fixity is still heavily integrated (and unquestioned) into the entire enterprise. To illustrate, a museum may accept an object into their collection, and (most often) the next step is to designate what it is (eg. using guides such as Chenall's Nomenclature or some other taxonomy), where it comes from, when it was made, and so on. Many of these characteristics are intrinsic, others are extrinsic and adtrinsic (provenance) but they are not sorted out this way. Once this object is accessioned into the collection then, it has been given an identity. This identity is often singular (e.g. A wagon wheel from 1864 made of wood and metal) or at least, is layered but from a single core. Then, the object is used in an exhibition. It is here that its identity can change based on what is needed for the exhibit. Once the object enters the public sphere in an exhibition or program, it can represent many meanings and may have multiple personalities/identities depending on how it has been situated and who might be viewing it. What is interesting here is that objects are often treated as monosemic (having only a single meaning) from any one party's standpoint, but in reality these add up to the object being polysemic (having multiple meanings). Clearly there is no single fixed point for an object (museum document). Who decides which is the correct one? While it may come into the museum as a certain type of thing and subsequently assigned an identity by the registrar or collection manager, once the object enters the public sphere, the point of fixity could change; its "origin" can vary, depending on the viewer's intention. Yet, museums often function as if an object=one meaning. If we could sort out the different kinds of informations in each document (or potential information based on document transactions), richer, more complex identities can arise from museum collections.

Thus far, I believe the most helpful conceptualization around this notion of fixed + fluid comes from Latour \& Lowe (2010) in a book chapter they wrote addressing the relationship between originals versus copies of art, (which I equate here with documents in general). While specifically questioning the notion of Benjamin's concept of aura in original works of art, Latour and Lowe (2010) make a good case for the "trajectory" or "career" of a work of art as the focal point of understanding rather than a single fixed point (object). The trajectory is likened to the catchment area of a river, not only focusing on the source of the water but the 
many estuaries, tributaries, rapids, meandering turns, and hidden sources associated with it. Their goal here is to render moot the question "is it original or is it a copy?" This contention directly relates to floating fixity:

...the real phenomenon to be accounted for is not the punctual delineation of one version divorced

from the rest of its copies, but the whole assemblage made up of one-or several-original(s) together

with the retinue of its continually re-written biography (p.4).

While here they are discussing the meaning of original and copies, their contribution to this current paper is the recognition of the moving "fixed" point, that is, that there is not a single one, which affects both fixity and authenticity. This notion of trajectory is very similar to what Wood and I (Wood \& Latham, 2014) discussed in the Objects of Experience when we referred to the life history of an object, but Latour and Lowe's expression is much more expansive and deeper. It provides us with a helpful analogy that can potentially be used in document institutions.

As promised, I will not end this article with a concise and clear conclusion, but rather more questions. In fact, Latour \& Lowe would likely agree with me that there are more questions than answers in this exploration. One can nearly hear them sigh a long breath as they say, "Originality once seemed so simple..." (Latour \& Lowe, 2010, p11). While the Document Phenomenology analysis helped in pulling apart what was going on in mybog experience story, the point that fixity and fluidity perpetually dance together through space and time affects all discussions of authenticity and what it means, especially in a document institution such as a museum. In museums, assumptions about authenticity as a fixed and defined point need to be continually questioned and deeply considered.

\section{References}

Abbott, P. (2016). Ireland's Peat Bogs. Retrieved from http://www.wesleyjohnston.com/users/ireland/geography/bogs.html on August 30, 2016

Dictionary.com. (2016). Peat bog. Retrieved from https://www.vocabulary.com/dictionary/bog on August 15, 2016.

Brown J.S. and Duguid, P. (1996). The social life of documents. First Monday, Volume 1, Number 1 - 6 May 1996. Retrieved from http://firstmonday.org/ojs/index.php/fm/article/view/466/387 on August 15, 2016.

Gorichanaz, T. \& Latham, K.F. (2016). Document phenomenology: A framework for holistic analysis. Journal of Documentation, 72(6): 1114-1133.

Grayson, K., \& Martinec, R. (2004). Consumer perceptions of iconicity and indexicality and their influence on assessments of authentic market offerings. Journal of Consumer Research, 31(2), 296-312.

Hede, A.-M. \& Thyne, M. (2010). A journey to the authentic: Museum visitors and their negotiation of the inauthentic. Journal of Marketing Management, 26(7-8), 686-705.

Latham, K.F. (2015). What is the real thing in the museum? An interpretative phenomenological study. Museum Management \& Curatorship, 30(1): 2-20.

Latham (2016a) Visitor perceptions of 'The Real Thing' in museums. Leibniz Research Alliance "Historical Authenticity." Museums-Places of Authenticity? International Conference, Mainz, Germany. March 2, 2016.

Latham, K.F. (2016). All museums are fake (and why that might not be such a bad thing). Keynote, 
$39^{\text {th }}$ Annual Historical Administration Symposium, Eastern Illinois University Historical Administration Program, April 9, 2016.

Latour, B., \& Lowe, A. (2010). The migration of the aura, or how to explore the original through its facsimiles. In T. Bartscherer (Ed.), Switching Codes (pp. 275-297). University Of Chicago Press.

Levy, D. (1994). Fixed or Fluid? Document Stability and New media.

ECHT '94 Proceedings of the 1994 ACM European conference on Hypermedia technology

Pp. 24-31

Merriam Webster (2016). Fixity. Retrieved from http://www.merriam-webster.com/dictionary/fixity on August 30, 2016.

Murray, A. (n.d.). Nature's Way: Biodiversity and Ecosystems in Ireland. An Taisce, The National Trust for Ireland.

Skare,, R. (2015) "Authenticity - An Important Property for Artistic Documents?," Proceedings from the Document Academy: Vol. 2: Iss. 1, Article 8. Available at: http://ideaexchange.uakron.edu/docam/vol2/iss1/8

Wood, E. \& Latham, K.F. (2013). The objects of experience: Transforming visitor-object encounters in museums. Walnut Creek, CA., Left Coast Press.

'Using the word "information" in this context is still a problematic term for me. But in order to move forward with testing out holistic document analysis, this is the placeholder we use until we get further application of the framework.

ii We use "object" very broadly to refer to the thing that a person is transacting with. 